\title{
Rethinking Digital Literacy Competencies of Indonesian Nursing Student in IR 4.0: Philosophical Context
}

\author{
Author: \\ Moch Aspihan, Ns., M. Kep., Sp. Kep. Kom¹' Dr. Moses Glorino Rumambo Pandin, M.Si., M.Phil., M.Psi., Psikolog²; \\ Prof. Dr. Kusnanto, S.Kp., M. Kes. ${ }^{3}$ \\ 1. Student of Doctoral Program in Nursing, Airlangga University; (moch.aspihan-2020@fkp.unair.ac.id) \\ 2. Lecturer in Nursing Philosophy Course, Faculty of Nursing, Airlangga University (moses.glorino@ fib.unair.ac.id) \\ 3. Lecturer in Nursing Philosophy Course, Faculty of Nursing, Airlangga University. (kusnanto@ fkp.unair.ac.id)
}

\begin{abstract}
Background: Industry revolution 4.0 (IR.4.0) paradigm, nurses were required to have adequate competencies to carry out their professional duties. Digital information should be mastered by the nursing student. Purpose: This study aims to explain digital literacy competencies on nursing students in the era of industrial revolution 4.0 in the Indonesian context. Methode: A literature review was conducted in this study using Rayyan Systematic Reviews Software. Results: There was 14 literature analyzed describing Student's Information literacy competency and Internet of Thing. Conclusion: Digital literacy for nursing students today is an inevitability, and nursing students who have digital literacy competencies have the potential to be able to increase nursing knowledge and skills as ontological competencies in their learning process.
\end{abstract}

Keywords: digital literacy, nursing students, competencies, nursing philosophy, IR 4.0

Background. Currently, we have entered the industrial revolution 4.0 where nurses as an integral part of health services are required to have adequate competence to carry out their professional duties. Nurse competencies are formed during at nursing education phase. The competence of health professionals explicitly states skills and behaviors (1). Competency standards for health workers in Indonesia require $40 \%$ of passing the competency test and $60 \%$ of the cumulative grade point average (GPA) (2). Passing the competency test is one of the important items in assessing the accreditation of study programs (3). The competency test is aimed at standardizing the competence of Indonesian health workers in providing complete health services to the public with the main principles of patient safety (4). However, not all nurses who graduated from academic education (especially fresh graduates) were declared competent.

The failure to pass the nurse competency test, both diploma III and Nurse level was still high in Indonesia. Based on the passing data of the Diploma III Nursing competency test in 2020, it was known that of the total participants, 11,611 (41.5\%) did not pass, out of a total of 27,939 participants (5). Meanwhile, the failures of the nursing diploma III program competency test were 4,145 participants (15.7\%) of a total of 26,359 exam participants (6). Failure to pass the competency test has an impact on nurses and the educational institutions where she or he studied. For the individual concerned, a fresh graduate nurse would be hampered in career development until was declared competent. Meanwhile, for educational institutions, it has an impact on the value of the feasibility of providing education based on an external quality assessment (3).

Various factors was been known that influence the passing of the competency test. Among them are exam readiness, academic achievement, the role of the institution, participation in tryouts (7), activeness in participating in learning programs, implementation of tryouts, and a cumulative grade point average (8). The cumulative grade point index was an indicator of the learning outcomes achieved by students at the end of the study (9). Other studies have shown that nursing student achievement is influenced by individual characteristics, affective factors, academic factors, environment, academic and affective 
outcomes (10). Therefore, to take advantage of opportunities and answer the challenges of the 4.0 industrial revolution, nursing students and nurses are required to have data literacy, digitization, technology, and human skills (11). Literacy support has a positive impact on improving student performance (12).

In the context of the industrial revolution 4.0 era today, there is a demand for Internet of Things (IoT) technology that allows every instrument to be connected virtually (11). Nursing human resources need to adapt and anticipate competence with new systems and equipment as well as technology-based, digital work procedures. Nurse literacy towards digitization and big data is very necessary to improve competence adapted to the industrial revolution 4.0. When nurses are digitally literate in various spheres at an advanced level it will help to more efficiently take other skills and competencies in his life. Nursing duties will experience efficiency and effectiveness with high stimulation in achieving service targets when nurses are literate and digitally literate (13). Therefore, to answer these challenges, an understanding of the potential use of information technology is needed which allows increasing literacy competencies for nursing students in the industrial revolution 4.0 era as a new education paradigm.

Purpose. This writing aims to explain literacy competencies for nursing students in industrial revolution 4.0 era based on Indonesian nursing student's context. This study refers to philosophical viewpoints including ontology, epistemology, and axiology. The questions that could be asked in this study are 1) What is digital literacy?; 2) How digital literacy became a competency for nursing students?; 3) Why digital literacy is valuable for nursing students?

Method. This paper begins the study by applying a narrative literature review related to the literacy competencies of nursing students. This paper seeks to provide an understanding of the literacy competencies of nursing students, especially at the Diploma III and Nurse education level. Articles are extracted from various database sources including Scopus, Science Direct, Proquest, and Springer. The keywords used are "literacy", "competencies", "nursing student" and "education". The inclusion criteria were applied in this search, namely the publication year 2019-2021 and in English. We found 116 articles consisting of Scopus 4, Science Direct 2 articles, Proquest 53 articles, and Springer 57 articles. This review process was carried out in several stages, and the Rayyan Systematic Reviews Software was used (14) . In the first stage, all articles are uploaded on the website https://rayyan.ai/. The next step was duplication screening so that 114 articles were found, and then we made a selection through titles and abstracts concerning PICOS so that 109 articles were included. Finally, we conducted a full-text analysis except for articles in the study of reviews, so those 14 articles were selected as units of analysis in this paper. Besides, to complete this study, we used some pieces of literature related to the purpose of writing.

Results. Based on the results of our literature reviews, we determined 14 research articles related to the application of information technology used in the learning process and the impact on information literacy competency on nursing students or health education students.

Student's Digital literacy competence. Information literacy (IL) ability of Indonesian students was found lower than two countries Malaysia and Thailand in basic and higher-level IL (students' ability to synthesize and evaluate various information problems and their products) but higher than others in intermediate level (15). Digital literacy had influenced directly on core competencies, which learning strategies mediated the influence and had a positive impact on core competencies among students (16). A case study used spiral learning framework described core competencies development after four years, integrating informatics program used, there were five domains of informatic competencies; health service literacy, ICT literacy, Information management, Information system literacy, Information system management, and patient/citizen digital health literacy (17).

\section{Using Internet of Things (IoT).}


A study on the internet using Iranian nursing students was found that $49.1 \%$ of the students used the internet from 15 to 60 minutes per day and nursing students were reported there was $44.8 \%$ had accessed computers and $47.6 \%$ accessed the internet (18). Framework for the Rational Analysis of Mobile Education (FRAME) model was used in clinical nursing practicum, findings of this study showed students in clinical practicums need learning materials that could be accessed ubiquitously for situated learning inwards, also revealed areas for improvements, covering the hardware scope of the devices, training on the use of apps and institutional support for the maintenance of the devices (19). Virtual learning had a significant impact on information-seeking skills and knowledge about search operators in nursing students (20). Virtual simulation significant developt in knowledge and acceptance of available treatment options for managing depression and schizophrenia over one year (21). Online social media were used in learning: youtube used in anatomy lecture (22) and Facebook (23). An online course could increase learning competency (24). Digital Learning Material (DLMs) used in nursing student's mathematic learning, there was a significant main effect was obtained regarding self-efficacy, mathematic learning outcome was improved and participants with high learning abilities showed the domain-specific instructional clips significantly more than participants with lower learning abilities (25). A study conducted on technology-mediated autonomous learning position in English for Specific Purposes (ESP) programs showed us that the majority of the students have a low level of readiness for technology-mediated autonomous learning situations (26).

A qualitative study was conducted on medical students to measure experience using games based on mobile, web, and virtual reality technology. Results of this study were stated that for the expert student there was a positive towards game-based learning in ordinary, the web version has the convenience of a huge screen, a mobile device has flexibility, and VR has angagement and specialized interaction. Respecting when the app is introduced in the educational context, they would acknowledge it both at the beginning of the education and additionally as applications available when practicing the procedure later on. For novice students, some favored mobile flexibilty while others approved the bigger screen available for the web form version. Positive towards VR if controls are customized, but a bit skeptical regarding lack of portability (27).

\section{Discussion}

In this discussion, we focus on the study of philosophy which consists of the viewpoints of ontology, epistemology, and axiology.

\section{1) What is digital literacy?}

Definition. Digital literacy is a term with synonyms E-literacy; ICT literacy; Internet literacy; Media literacy; New literacy. It was defined as a literacy concept that involves a variety of skills on the information handling, content creation, critical assimilation, analysis, and evaluation of information are at the basic of general literacy in the digital world (28). Confer to this view, digital reading and digital writing can be understood as reciprocal digital literacy exercises in the similar way that print-based reading and writing backgroud involve the interconnected act of writing. Digital literacy in scholars context was clustered views of any digital literacies into one of three dimensions: finding and consuming digital content, creating digital content, and communicating or distributing digital content (29). Heuristically, this concept was defined to conceptualize digital reading in the expansive framework of reading as literacy, involves a process of assimilation and construction situated in social and cultural practices (30). Definition of "digital literacy" has been stated digital literacy is the ability to figure out and use information from various digital sources. This means that it does not only include reading skills, but a critical thinking process is needed to evaluate information found through digital media (31). Competence or competency has defined a skill that is acquired by a certain set of tasks. Tasks can be executed if one has the relevant expertise (32). So, digital literacy competence can be defined here as a certain skill to use internet-based information from various sources. 
Indicators. Some indicators in this digital literacy concept, digital literacy as a competency for nursing students can be explained based on (17) consists of competencies for nursing students to 1) appreciate the basic categorize of health information systems such as administrative, clinical, and public health and their contribution to health care over time, 2) recognize the benefits, risks, and circumpection of health information systems such as electronic health records, clinical decision support systems, electronic prescribing, and telehealth/telecare systems; 3). get to know how the context is, in examples physical, social, cultural, economic, or political influence how ICTs are applied in practice by health professionals and patients; and 4). Identify appearing trends in ICTs such as Big Data, artificial intelligence and robotics, and their implications for nurses and patients/citizens. Digital learning consists of finding and consuming information, creating content, distributing and communicating, involving technology (29). Digital literacy includes several components which were text, activity, and reader. Reader in this context was characterized cognitive capability, reading and language competencies, reading dispositions and motivation, and sociocultural identities (30).

\section{2) How digital literacy became a competency for nursing students?}

There have been many studies in the realm of nursing education that have carried out technology-based learning methods. Epistemologically, nursing student's competencies were the term and conditions for nurse in nursing practice conducted. Based on Caritas thinking, discussion about the competency of nursing student, caring and healing and their applicability to nursing and health-sciences education are integrated into the framework (33). Digital literacy is one of the competencies for nursing students, these are valuable for them to face the challenge of rolling out information in the context of the education needed. If nursing students can adapt to current technological developments, they will survive with a variety of technology-based learning methods. So, the principal knowing of nursing students would be developed itself. According to Caritas framework, which stated: "every way of knowing becomes a way of living; thus, epistemology becomes ethic. Epistemology as ethic is a set of values to live by, a way to conduct our lives".

This emerging Caring Science epistemology-as-ethic is grounded in relationship-centered caring and enlarged consciousness of the power of teaching. A Caring Science was not a unitary thing, a singular and rule-bound belief system but it enlists with the diversity of the sciences and humanities and with assumptions of personal growth, of transformational learning by which t people think and speak can be changed in educative situations (33). In line with this thinking, then, when nursing students were able to apply the digital literacy process to be part of their mindset, it will be possible, these behaviors can become part of their life as students. This is a necessity that becomes the starting point for nursing students, especially in Indonesia, to be able to adapt to the demands of the times. Some studies have been conducted and showed to us there was a positive effect of digital directly or indirectly on nursing student's performance. Learning ability and self-efficacy of nursing students can be increased by Material Digital Learning Method (25).

\section{3) What is the value digital literacy for nursing students?}

The digital literacy concept seen from the perspective of the Iunsdutri 4.0 revolution is the embodiment of the Internet of Things (IoT). Recent research has shown that the use of the internet in the learning process can improve the competence of nursing students. Various methods and types of internet-based media have been tested and proven positively on student learning abilities like youtube, Facebook, virtual simulation, online course, and others method internet-based (12), (20), (22), (23), (24). These empirical pieces of evidence should be the basis for the development of a higher education curriculum in nursing. But, there is a question that should be answer based on Caritas' perspective in nursing. Refers to Watson's view of the Carative factor, promoting transpersonal teaching-learning, the extended Caritas process is closely related to the fundamental humanistic-altruistic value system and love and equanimity as consciousness. As a process, the education purpose on nursing should clearly 
state how to change Caritas nursing to be Caritas nurse, in other words, nurse competency must be able to show clearly Caritas nurse. Caritas nurse is working from a human to human connection, she or he is working from an open, intelligent heart center rather than the ego center. So, this caring consciousness direction informs the professional actions and relationships of a Caritas nurse, even while this one is engaged in the needed routine or dramatic, practical-technical world of clinical processes.

The next question is, will the total use of the internet-based in nursing learning be able to make students "as products" become Caritas nurses? the answer is of course not. Education in nursing based on Relationship-Centered Caring Model consists of four levels: 1) relationship with self, 2) patients relationship, 3) community Relationship and 4) practitioner relationship (33). We can state here is, internet-based nursing learning is at level one, as an "ontological competency" and usefulness. Therefore, the Internet of Things (IoT) is a certainty and inevitability of benefit for nursing students as a competency to developt individual knowledge and skills.

Conclusion. The passing of the competency test is influenced by the ability of students to take advantage of information technology which always develops according to its era. Nursing students who have digital literacy competencies have the potential to be able to increase nursing knowledge and skills as ontological competencies in their learning process. It has been proven that digital literacy that is applied in the educational process has a positive impact on students so that the hope of nursing education to get Caritas Nurses remains possible.

\section{Bibliography}

1. Waltz MJ, Moberly HK, Carrigan EE. Identifying information literacy skills and behaviors in the curricular competencies of health professions. J Med Libr Assoc [Internet]. 2020 Jul 2;1-5. Available from: http://search.ebscohost.com/login. aspx $?$ direct $=$ true $\& \mathrm{db}=\mathrm{rzh} \& \mathrm{AN}=145700923 \&$ site $=$ ehost-live

2. MINISTER OF EDUCATION AND CULTURE OF THE REPUBLIC OF INDONESIA. REGULATION OF THE MINISTER OF EDUCATION AND CULTURE OF THE REPUBLIC OF INDONESIA NUMBER 2 OF 2020 CONCERNING PROCEDURES FOR IMPLEMENTING COMPETENCY TEST FOR HEALTH STUDENTS. 2020;

3. (IAAHEH) TIAA for HE in H. Guidelines and Implementation of Assessment of Performance Documents and Self-Evaluation Reports for Accreditation of Nursing Diploma III Study Programs. 2019; Available from: https://lamptkes.org/en/Standard-7-Instrument-Download-file

4. Ministry of Research and Technology of the Republic of Indonesia. Implementasi Uji Kompetensi Nasional Bidang Kesehatan sebagai Langkah Konkrit Penjaminan Mutu Pendidikan Tinggi Kesehatan (Implementation of National Competency Assessment as Crucial Step for Quality of Higher Education). 2016;1-4. Available from: https://doi.org/No. 08/SP/HM/BKKP/IV/2016

5. Ministry of Research and Technology of the Republic of Indonesia. Data Statistik kelulusan Ners [Internet]. Available from: http://ukners.kemdikbud.go.id/pages/statistik_lulus

6. Ministry of Research and Technology of the Republic of Indonesia. Data Statistik Kelulusan Uji Kompetensi [Internet]. 2020. Available from: https://ukperawat.kemdikbud.go.id/index.php/pages/statistik_lulus

7. Hartina A, Tahir T, Nurdin N, Djafar M. Faktor Yang Berhubungan Dengan Kelulusan Uji Kompetensi Ners Indonesia (Ukni) Di Regional Sulawesi. J Persat Perawat Nas Indones. 
2018;2(2):65.

8. Lukmanulhakim, Pusporini DLS. The analysis of factors influencing graduation achievement in nurse competence test of nurse profession program. Cakrawala Pendidik. 2018;37(2):306-20.

9. Ministry of Research and Technology of the Republic of Indonesia. Peraturan Menteri Pendidikan Dan Kebudayaan Nomor 03 Tahun 2020 Tentang Standar Nasional Perguruan Tinggi. 2020;

10. Mthimunye K, Daniels FM. Predictors of academic performance, success and retention amongst undergraduate nursing students: A systematic review. South African J High Educ. 2019;33(1):200-20.

11. Sitinjak L, Tola B, Ramly M. Evaluasi Standar Kompetensi Perawat Indonesia Dengan Menggunakan Model CIPPO Menuju Revolusi Industri 4.0. 2019. 207 p.

12. Glew PJ, Ramjan LM, Salas M, Raper K, Creed H, Salamonson Y. Relationships between academic literacy support, student retention and academic performance. Nurse Educ Pract [Internet]. 2019;39(December 2018):61-6. Available from:

https://doi.org/10.1016/j.nepr.2019.07.011

13. Egbert N, Thye J, Hackl WO, Müller-Staub M, Ammenwerth E, Hübner U. Competencies for nursing in a digital world. Methodology, results, and use of the DACH-recommendations for nursing informatics core competency areas in Austria, Germany, and Switzerland. Informatics Heal Soc Care [Internet]. 2019;44(4):351-75. Available from: https://doi.org/10.1080/17538157.2018.1497635

14. Ouzzani M, Hammady H, Fedorowicz Z, Elmagarmid A. Rayyan-a web and mobile app for systematic reviews. Syst Rev [Internet]. 2016;5(1):1-10. Available from: http://dx.doi.org/10.1186/s13643-016-0384-4

15. Chusniyah T, Firmanto A, Kuswandi D, Jaafar JLSB, Chaiwutikornwanich A, Mustapa A. The Importance of Information Literacy to Face the Challenges of the Industrial Revolution 4.0: Study of Indonesian, Malaysian, and Thai Students. 2020;(February).

16. Kim KT. The Structural Relationship among Digital Literacy, Learning Strategies, and Core Competencies among South Korean College Students. Kuram ve Uygulamada Egit Bilim [Internet]. 2019 Apr;19(2):3-21. Available from: https://search.proquest.com/scholarlyjournals/structural-relationship-among-digital-literacy/docview/2222895492/se2 ? accountid $=31533$

17. Siobhan O'Connor a,*, Elizabeth LaRue b c a. Integrating informatics into undergraduate nursing education: A case study using a spiral learning approach. Nurse Educ Pract [Internet]. 2021 Jan;50. Available from: https://search.proquest.com/scholarly-journals/integratinginformatics-into-undergraduate/docview/2484266392/se-2? accountid=31533

18. Shirazi F, Heidari S, Fard SJ, Ghodsbin F. Pattern of internet use by iranian nursing students. Facilitators and barriers. Investig y Educ en Enfermería [Internet]. 2019;37(2). Available from: https://search.proquest.com/scholarly-journals/pattern-internet-use-iranian-nursingstudents/docview/2249282507/se-2?accountid=31533

19. Li KC, Lee LY king, Wong S lai, Yau IS yu, Wong BT ming. Evaluation of mobile learning for the clinical practicum in nursing education: application of the FRAME model. J Comput High Educ. 2019 Aug 15;31(2):290-310.

20. Shamsaee M, shahrbabaki PM, Ahmadian L, Farokhzadian J, Fatehi F. Assessing the effect of 
virtual education on information literacy competency for evidence-based practice among the undergraduate nursing students. BMC Med Inform Decis Mak [Internet]. 2021;21:1-11. Available from: https://search.proquest.com/scholarly-journals/assessing-effect-virtualeducation-on-information/docview/2490936985/se-2?accountid=31533

21. Liu W. The Effects of Virtual Simulation on Undergraduate Nursing Students' Mental Health Literacy: A Prospective Cohort Study. Issues Ment Health Nurs [Internet]. 2020;42(3):239-48. Available from: https://www.scopus.com/inward/record.uri?eid=2-s2.085089458331\&doi=10.1080\%2F01612840.2020.1793248\&partnerID=40\&md5=3048cfb36bf1f 19d680721c69ffe76d6

22. Mustafa AG, Taha NR, Alshboul OA, Alsalem M, Malki MI. Using YouTube to Learn Anatomy: Perspectives of Jordanian Medical Students. Muratori P, editor. Biomed Res Int [Internet]. 2020;2020:8. Available from: https://search.proquest.com/scholarly-journals/usingyoutube-learn-anatomy-perspectives/docview/2409698711/se-2?accountid=31533

23. Relucenti M, Alby F, Longo F, Miglietta S, Fatigante M, Familiari P, et al. Social media Facebook and You Tube usefulness in anatomy learning: experience at Sapienza University of Rome. Ital J Anat Embryol [Internet]. 2019;124(2):216-29. Available from: https://search.proquest.com/scholarly-journals/social-media-facebook-you-tube-usefulnessanatomy/docview $/ 2359354058 / \mathrm{se}-2$ ?accountid=31533

24. Theeke LA, Carpenter RD. Integrating an Online Statistics Course With a Graduate Nursing Research Course for Enhanced Learning. J Nurs Educ [Internet]. 2020 Apr;59(4):227-30. Available from: https://search.proquest.com/scholarly-journals/integrating-online-statisticscourse-with/docview/2385801997/se-2?accountid=31533

25. Effects of Digital Learning Materials on nursing students' mathematics learning, self-efficacy, and task value in vocational education. Nurse Educ Pract [Internet]. 2020 Mar;44. Available from: https://search.proquest.com/scholarly-journals/effects-digital-learning-materials-onnursing/docview/2425700521/se-2?accountid=31533

26. Alizadeh I, Ebrahimi F. Investigating medical students' readiness for technology-mediated autonomous learning situations in ESP programs. Educ Inf Technol [Internet]. 2019 Nov;24(6):3289-309. Available from: https://search.proquest.com/scholarlyjournals/investigating-medical-students-readiness/docview/2229509349/se-2 accountid=31533

27. Frøland TH, Heldal I, Sjøholt G, Ersvær E. Games on Mobiles via Web or Virtual Reality Technologies: How to Support Learning for Biomedical Laboratory Science Education. Information [Internet]. 2020;11(4):195. Available from: https://search.proquest.com/scholarlyjournals/games-on-mobiles-via-web-virtual-reality/docview/2387886515/se-2?accountid=31533

28. Seel NM, editor. Digital Literacy BT - Encyclopedia of the Sciences of Learning. In Boston, MA: Springer US; 2012. p. 992. Available from: https://doi.org/10.1007/978-1-4419-14286_3813

29. Loewus L. What Is Digital Literacy? 2006; Available from: https://www.edweek.org/teachinglearning/what-is-digital-literacy/2016/11

30. Coiro J. Toward a Multifaceted Heuristic of Digital Reading to Inform Assessment, Research, Practice, and Policy. Read Res Q. 2021;56(1):9-31.

31. Akhirfiarta BT. Literasi Digital pada Pegawai RSUD dr. Soetomo Surabaya Brilian Trofi Akhirfiarta 1071311633083.2017 ; 
32. Seel NM. Encyclopedia of the Science of Learning. 2012.

33. Simms LL, Watson J. Nursing: The Philosophy and Science of Caring. Vol. 79, The American Journal of Nursing. 1979. 2040 p. 